\title{
THE DEVELOPMENT OF REGION LEARNING CONCEPT IN INCREASING REGIONAL COMPETITIVENESS
}

\author{
Muttaqin Andhyka \\ Department of Public Administration, Faculty of Administrative Science, \\ University of Brawijaya, Indonesia \\ E-mail: andhyka@ub.ac.id
}

\begin{abstract}
The development of regional industries is an essential thing for the continuity of certain local economic conditions to improve regional economic competitiveness. Each region has its own advantages and disadvantages which can be seen from the sector of human resources, natural resources, government, and main capital industry that acts as a very strong base for the development of a certain region. Taking into account the current condition of industrial development in Indonesia at national and regional levels and to increase competitiveness, the industrial development must be synergized with the national (central) planning and the regional planning. This can be done by two approaches which are top-down approach and bottom-up approach. In industrial development, a top-down approach is planned with relation to nationally determined priorities which then followed by regional participation. This is generally known as national design (by design) development. Meanwhile, a bottom-up approach is done by determining the superior core competency of a region. The use of core competencies as a leading regional area is intended to build and to improve regional competitiveness.
\end{abstract}

\section{KEY WORDS}

Competitiveness, region, learning, regional development.

Today, it almost becomes a mainstream (or at least begin to develop) development approach that increased competitiveness in various forums and social cohesion is believed to be a determinant of success in improving the welfare of the people to be higher and fairer on an ongoing basis. In other words, the step of increasing competitiveness and social cohesion also needs to be seen as an integral part of poverty reduction as a form of inequality.

Concept review and some empirical evidence of several successful practical experiences show that competitiveness and social cohesion of a state, region, or community are strongly influenced by the "innovation system" development of the state, the region, or the community concerned. The dynamics of the innovation system point out the capacity of the nation to master, utilize, and develop the knowledge, innovate and diffuse the innovations, process the learning, and adapt to various changes.

Innovation and diffusion of innovations as sources for improvement are the keywords that can no longer be ignored. Innovation no longer has to be considered an exclusive "item" to certain groups or advanced community groups. Innovating and diffusing innovation must become a "tradition" in a state, region, or community; willing to become more prosperous and do not want to be "marginalized" in the governance of international life today.

Building competitiveness and strengthening social cohesion requires a strong foundation and ability (capacity) to be realized. Developing/strengthening innovation system will increasingly determine the success of economic development at the national and regional level in improving the welfare of the society, reducing poverty, and facing challenges in preparing the society to enter the era of a knowledge economy and knowledge society. This study is a collection of brief discussion on how the best policy innovation, as a set of various interrelated policies to influence the development/reinforcement of innovation system (either at the national, regional, or industrial/sectoral level), is developed/strengthened as an integral part to make Indonesia more prosperous, equitable, and advanced. 
The core competency of a region determines the direction of the regional development that is aimed to increase the regional economic level as well as to create regional competitiveness and national competitiveness. The characteristics of regional core competencies are: developing new products, services, and prospects for the public and possessing something unique that other regions will difficult to copy.

The use of core competencies in the development of regional industries is quite relevant for the purpose of increasing regional competitiveness and national competitiveness. This can happen considering that the approach of core competency tries to exploit the strengths and advantages of the region in a unique way. Core competency is defined as a set of skills and technology allowing an organization to uniquely provide its own benefits to its customers. This is applied to regional industrial development by trying to exploit resources and organizational capabilities uniquely. This uniqueness is a value that other regions do not have and therefore will be an advantage for the regions that have it. The application of core competencies nationally can be implemented by introducing a unique product in each different region. This is done so that all the resources and capabilities possessed by the area are focused on the efforts to create unique core competencies.

In accordance with the source and development of the core competency concept, building core competencies (whether in the form of products, services, or commodities) should pay attention to the criteria that are relevant to the need for increased competitiveness such as uniqueness (inimitable), ability to give more benefits, or the ability to benefit from a more efficient partnership. In the regional context, the selection of core competencies needs to consider the condition of the area while still taking into account the criteria of competition such as high added value, unique characteristics, and linkages and opportunities to compete in markets outside the region (even international markets).

There are many driving determinants of productivity competitiveness in a country, nation, or region, that based on the World Economic Forum (WEF) are grouped into 12 pillars of competitiveness, namely:

- Institution,

- Infrastructure,

- Macroeconomics,

- Health and basic education,

- Higher education,

- Goods market efficiency,

- Labor market efficiency,

- Financial market,

- Technology readiness,

- Market size,

- Business sophistication,

- Innovation.

Furthermore, those 12 pillars are classified into 3 pillar groups, namely: basic requirements group, efficiency support group, as well as group innovation and business sophistication. In estimating the competitiveness of each country, each pillar gets a different weight depending on the state's economic progress by taking into account that the same indicators have different effects on different stages of state's economic progress. The economic stages in question are: initially, the economy tended to be driven by natural factors (such as natural resources and unskilled labor) but then it was driven by efficiency factors and in the final stage, by innovation.

In general, the concept of learning organization/learning region can be defined as the ability of the organization/region to do the process of self-learning on an ongoing basis. By that, the organizations have the 'speed of thinking and acting' in response to various changes that arise. In a learning organization/learning region, there are 2 methods that can be used namely single-loop and double-loop learning. Chris Argyris introduced the theory of singleloop learning that today is also used in business management. 
In conducting the learning process, it is not expected that the organization will succeed optimally if they only apply the method of single-loop learning; improving the service quality only when errors occur based on experiences and current policies. In order to achieve optimal organizational learning, the learning process should be done with double-loop learning that is conducting a learning organization not only based on error factors but also reevaluating the organization even without error in order to improve the quality of the company (Kim, 1993). The principle of double loop learning is assumed to be more eminent if it is compared with single-loop learning because double-loop learning can produce innovation in service efficiency and effectiveness. Meanwhile, if only through the single-loop learning, it will produce a problem solving that might be not efficient and effective.

According to Peter Senge in his book "Fifth Discipline", it is stated that in the characteristics of a learning organization/learning region, there are five disciplines or dimensions that need to be developed. The five disciplines are:

- Personal Mastery: the ability to continuously and patiently improve insight to be objective in seeing the reality by focusing the energy on strategic matters.

- Mental Model: a process of assessing oneself to understand assumptions, beliefs, and prejudices on the stimulation that arises.

- Shared Vision: the commitment to explore a shared vision of the future purely without coercion.

- Team Learning: the ability and motivation of a group to learn adaptively, generatively, and sustainably.

- System Thinking: the ways of speaking and thinking to describe and understand the strengths and relationships that determine the behavior of a system.

The fifth discipline factor (system thinking) helps the people to see how to change the systems more effectively and how to take actions that are more in line with the interaction process between the components of a system and its environment. The practice of these five disciplines is not easy to realize in the activities of regional government organizations. For example, discipline regarding shared vision; an organization will not be able to harmonize and synergize the ideals in the future together if there are obstacles in the implementation of fairness and in government organizations. The major issues in our Regional Government are the circle of injustice in the affairs of regional government administration implementation.

However, in the aspects of those five disciplines, there are still some efforts that can be made by our Regional Government in realizing a learning organization/learning region. The regional government's efforts in realizing the learning region can be done by fully understand the five disciplines as the basic characteristics of a learning organization. From the explanation, the purpose of this writing is to construct a concept that is utilized by private sectors so that it can be adapted and implemented in the public sector.

\section{LITERATURE REVIEW}

The System of Innovation and Regional/Collective Learning. The increasing popularity of regional innovation system concepts has become a part that has been driven by an increase in the intensity of international competition in economic globalization. Besides that, the lack of traditional regional development concepts and policies is increasingly visible and the success of clusters for companies and industries in several regions also seems to increase. Many academics found that regional scale, as well as regional and specific resources, have an important role in stimulating innovation capabilities and competitiveness of a company and a region (Asheim et al.; Wolfe; Isaksen, Malmberg, and Maskell). In a learning economy, which indeed is also a knowledge-based economy, competitive advantage is based on the exploitation of unique competencies and resources. A company or a region competes based on the uniqueness of each competitor. Therefore, there is a strategic perspective in contemporary global economics that is the way to develop unique competencies and resources to encourage competitiveness based on competitive advantage. This statement argues that specific competencies of a company and its learning process can trigger the competitive advantage of a region if it is based on local capabilities 
such as distinctive resources, skills, institutions, social cohesion, and cultural values. In other words, regional development will have competitiveness if it is carried out in a place where local capabilities such as "endowment" institutions, structure development, and knowledge and skills are present. Some literature on regional innovation systems has provided an overview and analysis of the relationship between innovation, learning, and economic performance in a region (regional).

Some of the theories and concepts that are related to regional development such as regional economic development, innovative milieu, regional innovation system, and regional learning emphasize the importance of institutional and social factor. In terms of the important factors, Gertler, Boschma (2005) and Malmberg and Maskell underlined that geographical proximity is not enough to facilitate the regional collective learning. The types or variant of the proximities are (1) cognitive (understanding), (2) social (trust, intimacy), (3) organization (network-hierarchy), and (4) institutional (language, habits, and routine). The approach of system innovation sees innovation as a result of the systemic interactive learning process and considers institutions as rules and regulations in which patterns of behavior may have a conducive effect on the learning process.

Competitive advantage is not limited to the acquisition of codified knowledge and capital available throughout the world but depends on the institutional and social capital that drives the acquisition and use of codified and tacit knowledge. Improvement, both in terms of institutional and social variables, affects the capacity at regional and local levels. In addition to that, the focus on the regional level is to provide a better way to understand the innovation process in diverse economic, social, and political realities. The various types of norms, conventions, and practices are expected to have important implications for the creation of knowledge and learning that shape the pattern of economic interactions, either within the company and other organizations or in between them. Finding and explaining patterns of interaction that lead to dissemination, creation, and use of knowledge is part of the innovation approach.

The "innovation system" approach is used to analyze the network of relationships between companies and institutional arrangements that support innovative activities in a broader sense; the framework emphasizes the dynamic and cumulative nature of the innovative process. Analyzing this relationship also involves tracing of knowledge flow amongst public and business institutions that form an innovation system. This study shows the interdependence of economic, political, and cultural factors and the increasing importance of closeness in influencing the innovation process.

Doloreux has pointed out the principle of internal mechanisms involved in the regional innovation system approach. First, interactive learning must be able to improve the knowhow information of the company, reduce fixed costs in the procurement and distribution, affect the management speed, and reduce the uncertainty in the technological innovation. Second, there must be a production of knowledge where knowledge is developed and disseminated. Number three, closeness must create benefits in grouping space, increase the speed of communication between companies, and reduce related costs. After that, there needs to be a social attachment which becomes a consideration in the rules of human relations and professional networks. Lam (2000, in Ashim, 2004) confirmed that learning and innovation cannot be separated from the broad social context when analyzing the interrelationships between knowledge types, organizational formats, and social institutions within the framework of finding particular industry needs.

The concept of learning region appears to comprehensively describe the right institutional environment to encourage the private and social learning at a different scale; as for examples, an individual worker or a group in a particular company or in a government environment. However, it is found that the literature on learning region contains a number of ambiguities and inconsistencies.

There are three central ideas of a learning organization. The first idea explains that the learning process depends on the knowledge that spreads among the members of the organization. Most of this tacit knowledge comes from the learning process and is manifested in organizational routines and procedures. On the other hand, the second idea says that 
generating new knowledge in organizations depends on the combination of diverse knowledge. Last but not least, the third idea is in concern with organizational inertia that companies may find it difficult to effectively use the new knowledge. This happens because the companies face resistance to make changes in organizational routines and procedures where the knowledge is realized.

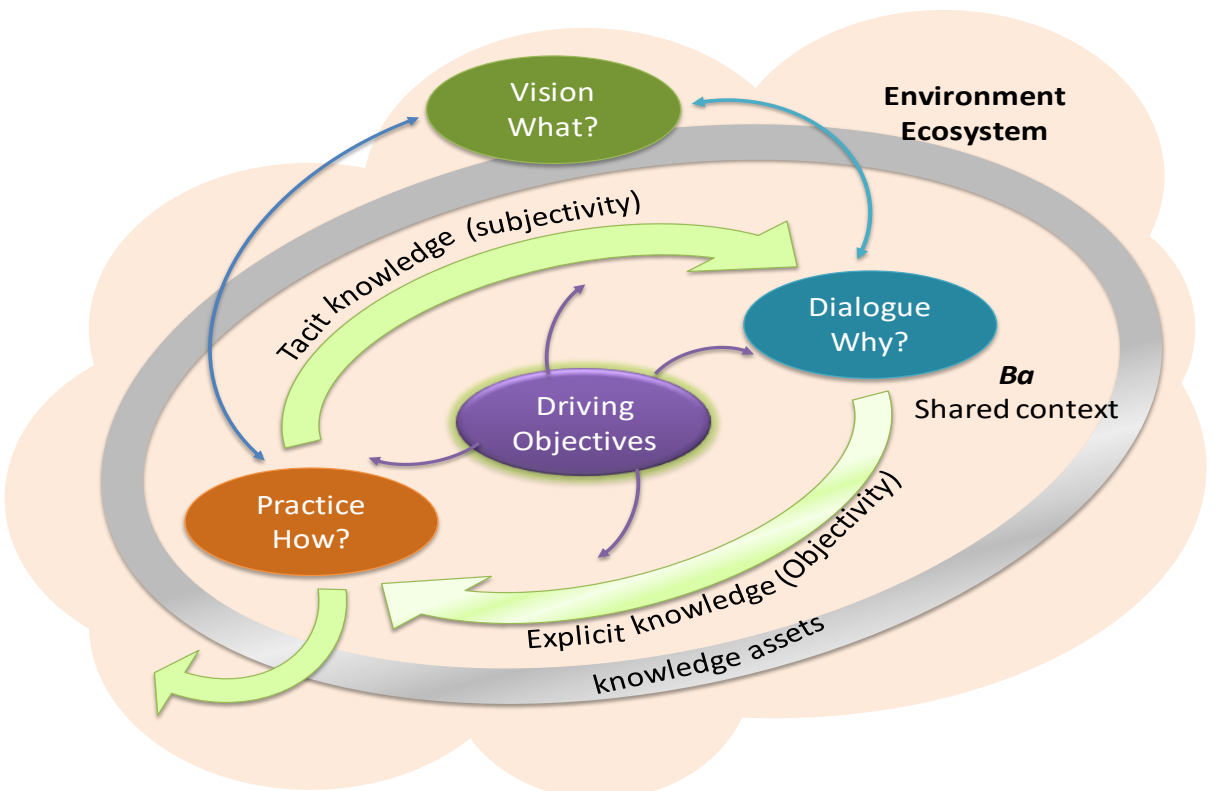

Figure 1 - The Illustration Of Learning Regional Concept (Source: Lawson and Edward Lorenz, 1999)

The concept of collective learning was first introduced by the Groupe de Recherche Europeen sur les Innovateurs Milieux through regional (local) development literature in the 1980s. The concept of collective learning lies in the heart of innovateur milieu theory and refers to the existence of general knowledge which exceeds the corporate boundaries but remains in the spatial boundaries of the environment (Capello, 1999). Afterward, this concept has been further developed by Cambridge groups (Keeble and Wilkinson, 1999, 2000a, b; Lawson, 2000; Lorenz, 1996). They have explicitly developed the concept of collective learning to be in line with a broad understanding of regional innovative capacities to produce or facilitate the learning process and innovative behavior by the members of the environment (Keeble, 2000; Aydalot, 1986; Keeble et al., 1998; Camagni, 1991). This means that knowledge is basically seen as a social construction and not as a set of truths. This concept involves a close relationship between scientific processes and practical reasoning, including storytelling and interests forming.

There are several definitions of collective learning but in general, the writer of this study refers to the process of social learning that is based on the joint rules and procedures which allow individuals to coordinate their actions in solving a problem (Capello, 1999; Rallet, 1993). Based on the works of literature and a writer's understanding of collective learning, the writer defines collective learning as an interactive process of gathering knowledge from different local resources.

In this context, clusters combine a number of different actors. As a result, collective learning can be conducted in many forms such as a collaboration in research and development teams or joint research projects for education and training seminars (Malmberg and Maskell, 2006; Anselin et al, 1997). However, it can also be done in a less informal manner such as meetings at local restaurants, lobbying from local organizations, networking with fellow graduates, or other social networking events (Steiner and Hartmann, 2006). Malmberg and Maskell (2006) have identified three main sources of shared learning in a group related to the dimensions of vertical, horizontal, and social. 
As part of an interactive process that is oriented on learning activities, various forms of learning seem to play a role in:

- Cognitive learning, learning that contributes to capturing the understanding of a particular situation or a problem. In the environmental context of many models and complex problems, cognitive learning abilities will include the ability to work in disciplinary fields and to link analytical skills with competency-oriented actions (Verkaik, 1997);

- Social learning, learning that increases the understanding of other involved actors and its actions (Vermeulen et al, 1997). Although cognitive aspects also important, the interactive learning process attracts strong forms of learning;

- Institutional learning. In this matter, the formation and embedding of routines, attitudes, and organizational forms that support learning are emphasized. Since institutional set-up is a socio-cultural phenomenon, they differ greatly between regions and nations.

Regional Core Competency. Regional core competency is a unique superiority of an area that cannot be replicated by other regions and based on certain resources such as natural resources, human resources, local environment, and community prospects. There are two types of regional competencies namely primary product competencies in the form of Human Resources, Natural Resources, local environment, and local culture, and secondly, processed product competencies in the form of technology, infrastructure, and products. A core regional competency is crucial in determining the direction of regional development which aims to improve the economic level of a region and create competitiveness from the regional level to the national level.

The characteristics of core regional competencies are:

- Developing a new product/service which can be prospected to the public in general;

- Having something unique cannot be imitated by other regions.

Competence is a basic characteristic of a person that allows oneself to produce superior performance in the work. According to Trotter in Saifuddin (2004), competent people are those who have the skills to work easily, quickly, intuitively, and very rarely or never make mistakes. Boyatzis in Hutapea and Nurianna Thoha (2008) said that competence is the capacity of someone in fulfilling the work requirements of an organization so that the organization can achieve the expected results. Meanwhile, Websterís Ninth New Collegiate Dictionary in Sri Lastanti (2005) defined competency as the skills of an expert. In that case, experts are defined as someone who has a certain level of skill or high knowledge in certain subjects obtained from training and experience. Byars and Rue (1997) also wrote that competence is a characteristic needed by a position holder so that he/she can carry out its position well or in other words, it is the apparent characteristics of a person including knowledge, expertise, and behavior. The consideration of competency requirements includes:

- Future requests are related to the organization's strategic, operational goals, and objectives;

- Anticipating the needs of management A006Ed employee shift;

- The changes in organizational processes, technology, and equipment;

- The evaluation of employee competencies in carrying out the activities and processes specified.

Based on the description above, the meaning of competency contains a profound and inherent part of someone's personality along with its predictable behavior in various situations and work tasks. The performance of someone can be measured by the criteria or standards used. Competency analysis is mostly constructed for career development, but the determination of competency level is needed to determine the effectiveness of performance level that is implemented. Based on the explanation from Boulter et al (1996), the level of competence consists of Skills, Knowledge, Self-Concept, Self-Image, Trait, and Motive.

Skill and Knowledge Competencies tend to be more visible and relatively can be seen on the surface as characteristics of someone whereas social roles and self-images tend to 
be less visible and can be controlled by outside behavior. As for trait and motivation, both of which are located deeper at the central point of personality. On the other hand, the competence of knowledge and expertise is relatively easy to develop as for examples, it can be done with training programs to increase the level of human resource capacity. It is quite difficult to assess and develop the potential and trait motives of someone since both of which are resided in the personality. One of the most effective ways of that issue is to choose these characteristics in the selection process. The self-concept and social role are located between those two characteristics and can be changed through training; psychotropic itself requires a longer time and harder effort. Antonacopoulou and Gerald (1996) stated that competency consists of the unique characteristics of each individual that is expressed in the process of interaction with other parties in a social context. Therefore, it is not only limited to the behavior, specific knowledge, and skills or performance standards that are presented. It can be said that competencies include attitudes, perceptions, and emotions and emphasize the personal and social factors of interaction.

Competency Standards and Aspects. The concept of competency includes several aspects, among others: the basic framework in which competencies are constructed by involving standard measurements recognized by the relevant industry. The other aspects of this competency are not only shown to other parties but must be proven in the work functions. Each individual must realize that knowledge is an added value to strengthen the organization. Competency must be a value that refers to the satisfactory performance of individuals. In other words, competence must be closely related to the ability of someone to carry out the tasks that reflect certain requirements. In addition to that, competency standards are a form of skills and knowledge that must be owned by someone to perform a certain task. It also can be said that competency standards are statements regarding the implementation of tasks in a work described in the form of output.

The second competency according to the research results is the ability to manage changes, among others, able to build trust and credibility in dealing with other parties, have a proactive vision in change, willing to develop supportive relationships with other parties, able to encourage the creativity of others like the subordinates, able to place specific problems in the broader context of the system, and can identify the main problems in business success.

The ability to manage culture is the third competency that is needed by human resources. In this case, it includes several capabilities such as the competency to share knowledge across organizations in organizational boundaries, the ability to advance the process of cultural transformation, the ability to interpret the culture into specific behaviors, the competency to challenge the status quo, the ability to recognize the culture in finding the company's business strategy and cultural frame to stimulate the employees, the ability to encourage the executives to behave consistently with the culture, and then the focus in internal culture to determine and fulfill the needs of external customers that will determine the success of a company because without satisfying the external customers, the efforts will be meaningless.

Nevertheless, there is the delivery of human resource practices as the sixth competence in human resources. This competency covers a wide range of capabilities including the ability to express verbal communication effectively, the ability to work with managers to send clear and consistent messages for all involved actors in the organization, the ability to facilitate the organization's restructuring process, the ability to design development programs that facilitate the change, the ability to facilitate the design of internal communication, the ability to attract the right employees, the ability to design compensation systems, and last but not least, the ability to facilitate the dissemination of customer information.

The last competency is the ability to understand the business where this competency is further specified into an understanding of human resources practice, organizational structure, analysis of competitors, financial management, marketing and sales, and computer information systems. According to Walsh et al (2001), basic competence is a broad skill about production and corporate technology that supports organizations to adapt quickly to opportunities that arise. 
Furthermore, the company identifies the competencies that are relevant to a particular industry. The indicators of technical competence are:

1. Education Level. Education is an educational level requirement that is needed for a position and is usually related to an intellectual level. Education is a minimum requirement in an organization/company.

2. Work Experience. Work experience is the length of time of someone in handling a certain role or position and executes it with good results.

3. Analysis Ability. The ability to understand the situation by splitting it into smaller parts or the ability to observe the implications of situation step-by-step based on past experience. Non-technical competence refers to the ability to control and stimulate oneself in a work task (Nefina, 2005). Non-technical competence covers individual characteristics such as motivation, behavior, and personality. This competency does not involve employees that are related to programs or technical issues. Based on the research from Hutapea and Nurianna Thoha (2008), the indicators of non-technical competence are as follows:

1. Self Control. The ability to control emotions in order to avoid doing something negative when the situation is not under control or when facing under pressure situation.

2. Self Confidence. The level of credibility in completing the employees.

3. Flexibility. The ability to adapt and work effectively in various situations and in between people or groups.

4. Relationship Building. The ability to build or maintain friendliness, warm relationships, or networks communication with someone that one day might be useful to achieve work goals.

Concept of Competitiveness. A competitiveness strategy will be effective if it is able to combine macro-level efforts in improving the investment climate through initiatives aimed to develop key industrial cluster competition. Macro-level efforts can support the ranking of national competitiveness through Balanced Scorecard as a monitoring and strategic analysis tool. Complementing this case, cluster-oriented development policies need new instruments for innovative analysis and approaches to make new economic policies that able to break traditional sector boundaries and administrative boundaries. Therefore, the concept of an industrial cluster is the center of an approach.

The discussion about "regional competitiveness" itself produces various definitions. The first one is area competitiveness (locality and region) which is the ability of the local economy and community to improve the living standards of the citizens/residents. Competitiveness is the ability to produce goods and services that meet international testing, and at the same time, can maintain a high and sustainable level of income. In other words, it is the ability of the region to produce high levels of income and employment opportunities by remaining open to external competition. Regional competitiveness can be defined as the ability of the constituent members to take action in ensuring that the businesses in the area sell higher levels of added value in international competition. This can be maintained by the local assets and institutions which then will contribute to the increased GDP and a wider distribution of welfare in the society. Besides that, it also produces a high standard of living and virtuous impact on learning. Regional competitiveness is related to the ability to attract foreign (external) investment and determine its productive role.

Other than that, there is urban competitiveness that is the ability of an urban area to produce and market its products similar to products from other urban areas. Regional competitiveness is the ability of the regional economy to achieve a high and sustainable level of prosperity by remaining open on domestic and international competition. Regional scientists have long been attracted to clusters as networks of innovation. This can be seen from the growth in accordance with the 1960s and 1970s literature. This interest has been revived by the latest literature on the regional industry that it reminds the writer about the analysis from Marshal who investigated the industry in 1890 focusing on Italy and other European countries. In the end, the literature pays attention to the development of technology that focuses not only on individual companies but also emphasizes the importance of interaction between consumers and its complementary (suppliers and competitors, where competition is part of the strategy, tactics, and incidental cooperation). 
Innovation and diffusion depend on the network of institutions that often describe the regional system. It is believed that the geographical condition eases the collaboration and competition. In this matter, cluster-based policies operate at different levels.

Thus, Indonesia has a comparative advantage in producing coffee and Malaysia has a comparative advantage in producing tin. The trade will be mutually beneficial if both countries are willing to exchange coffee and tin. However, in the framework of world coffee trade, Indonesia's competitive advantage is greater than Malaysia to compete in the international market. On the other hand, in the Tin trade, Malaysia has a better competitive advantage than Indonesia. In the context of regional development, "country" in this concept can be analogous to "region". One thing that can be taken from the concept of comparative and competitive advantage is the importance of effectiveness and efficiency in the production or management of regional resources to increase its power.

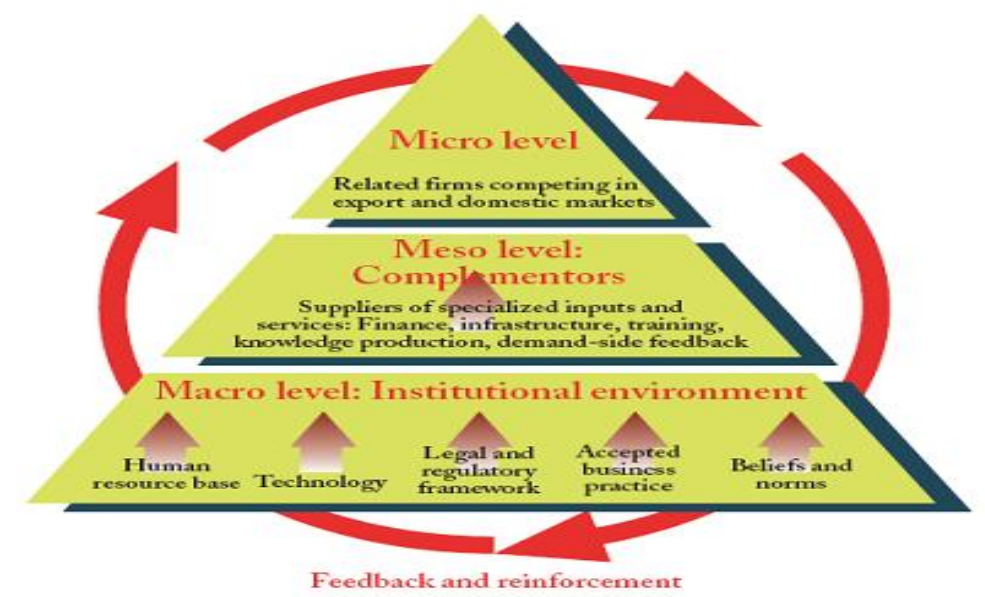

Figure 2 - The Figure of Cluster Analysis (Source: Roelandt, Theo J.A. and Pim den Hertog (eds.), 1998)

Regional competitiveness will closely related to local economic development (LED). One of the approaches in local economic development is a regional approach that is how to increase collective efficiency and optimize the use of resources that exist in the neighboring areas. By that, regions can also strengthen the competitiveness in higher levels (national and global). The efforts from various regions to foster cooperation between regions in promoting regional potential (regional marketing) is one example of a regional approach.

Regional Strategy. Realizing a region that has such competitiveness, one of which is to innovate in improving the quality of public services, development, income management, and governmental services management that are compulsory or elective so that the regions will have competitiveness at national and international levels. The measurements on the implementation of innovation success can be done by comparative methods and performance measurement properties. The comparative method is done by comparing the success and failures. This is not solely about a study tour to regions/countries that certainly if not well planned would be ineffective and inefficient. However, with the comparative method, this will involve the community participation in governance. The success of innovation based on the nature of performance measurement needs to be emphasized in the structure of work, leadership, and incentives provided proportionally and professionally.

The innovations carried out by various levels have a high resistance to the obstacles that arise in the process of ongoing innovation. By looking at the opinion of Mulgan \& Albury (2003), the obstacles that often arise in making innovations are: (1) Administrative pressure and burden; (2) Short-term budget and future planning; (3) Lack of rewards and innovation incentives; (4) Facing risks culture; (5) Low skills in facing risk and change management; (6) Reluctance to end failed programs or organizations; and (7) Availability of technology, cultural constraints and institutional arrangements. Empirical research shows that there are high variations on how to overcome the barriers of innovation which in this case, there are 
three approaches which include: persuading, accommodating, and others (diversity of responses).

Based on the empirical study conducted by Grindle (2007), there are four propositions that can explain why regional governments need to innovate in order to increase their economic growth and improve people's welfare. The first is political competitions. The dynamics of local political competition are the essence of an approach that explains the variations in the performance of regional government in a democratic manner. Secondly, there is state entrepreneurship that is centered on the activities of regional government institutions in terms of the authority to develop innovative ideas and strategic choices about the added value of a policy. Number three, public sector modernization. This is associated with the provision of additional incentives for public officials who have made institutional restructuring, privatization of services and contracting out, as well as technological innovation to develop the capacity of the public sector. Last but not least is civil society activism which increases the degree of participation and accountability of social groups in the local community, directed to provide excellent public services including in the participation in the policy process. Looking at the four propositions, it can be understood that the involvement of the community or the private parties in the innovation of governance requires the support of democratic political process, entrepreneurial knowledge of the government, modernization in the public sector management, and public participation improvement.

\section{CONCLUSION}

A region needs to have a competitiveness strategy that will be effective if it is able to combine macro-level efforts to increase investment climate through initiatives aimed to build key industrial cluster competition. Besides competitiveness, core competencies of a region is a unique advantage of an area that cannot be imitated by other regions and based on a number of specific resources such as natural resources, human resources, local environment, and community prospects. In this competency, the region is divided into two types of regional competencies, namely primary product competency in the form of human resources, natural resources, local environment, and local culture and then processed product competencies in the form of technology, infrastructure, and products. A core regional competency will greatly determine the direction of regional development which aims to improve the economic level of an area and create competitiveness from the regional level to the national level. Therefore, regional learning approach is essential in carrying out regional development planning, not partial or instant but on an ongoing basis. By developing regional learning concepts, the region will know its weaknesses and strengths in increasing regional competitiveness.

\section{REFERENCES}

1. Abdullah, P. (2002). Daya Saing Daerah: Konsep dan Pengukurannya di Indonesia". Pusat Pendidikan dan Studi Kebanksentralan Bank Indonesia. Yogyakarta: BPFE. Yogyakarta.

2. Abdurahman, B. (2005). Pemahaman Dasar Regional Management \& Regional Marketing. Jakarta: IAP.

3. Anselin, L. A. V. \& Acs, Z. 1997. Local geographic spillovers between university research and high technology innovations. Journal of Urban Economics, 42(3), 422-448.

4. Asheim, B., Coenen, L., \& Svensson-Henning, M. (2003). Nordic SMEs and regional innovation systems. Oslo: Nordisk Industrifond.

5. Aydalot, P. H. (1986). Milieux Innovateurs en Europe. Paris: Groupe de Recherche Européen sur les Milieux Innovateurs dalam Anja Cotic-Svetina, Marko Jaklic and Igor Prodan, Does collective learning in clusters contribute to innovation? Science and Public Policy, 35(5), 335.-345. 
6. Bjørn, T., Asheim., \& Lars Coenen. (2004). The Role Of Regional Innovation Systems In A Globalising Economy: Comparing Knowledge Bases And Institutional Frameworks Of Nordic Clusters, Paper at the DRUID Summer Conference 2004, Elsinore, Denmark.

7. Boschma, R. A. (2005). Proximity and Innovation: A Critical Assessment. Regional Studies.

8. Camagni, R. (2002). On the Concept of Territorial Competitiveness: Sound or Misleading? Urban Studies, 39, 2395-2411.

9. Capello, R. (1999). Spatial transfer of knowledge in high technology milieux: learning versus collective learning processes. Regional Studies, 33(4), 353-365.

10. Capello, R., \& Faggian, A. (2005). Collective learning and relational capital in local innovation processes. Regional Studies, 39(1), 75-87.

11. Centre for Urban and Regional Development Studies. (2000). UK: University of Newcastle Upon Tyne.

12. Cooper, P. J., et. al. (1998). Public Administration for the Twenty-First Century. Orlando: Harcourt Brace \& Company.

13. Gertler, M. (2003) Tacit knowledge and the economic geography of context, or The undefinable tacitnes of being (there). Journal of Economic Geography, 3, 75-99.

14. Gertler, M. S. (2004). Manufacturing Culture: The Institutional Geographyand Industrial Practice. Oxford: Oxford University Press.

15. Gordon, I. R., \& McCann, P. (2005). Innovation, agglomeration, and regional development. Journal of Economic Geography, 5(5), 523-553.

16. Isaksen, A. (2003). Knowledge-intensive industries, clustering, and regional development. Norway: Urban Studies (Forthcoming).

17. Johnson, B. (1997). Systems of Innovation: Overview and Basic Concepts. In: Edquist, C. (Ed.): Systems of Innovation. Technologies, Institutions and Organizations.

18. Keban, Y. T. (2004). Enam Dimensi Strategis Administrasi Publik: Konsep, Teori dan Isu. Yogyakarta: Gava Media.

19. Limerick, D., \& Cunnington, B. (1993). Managing the New Organization: A blueprint for networks and strategic alliances. West Castwood Australia: Business \& Professional Publishing.

20. Malmberg, A., \& Maskell, P. (2002). The elusive concept of localization economies: towards a knowledge-based theory of spatial clustering. Environment and Planning A, 34(3), 429-449.

21. Malmberg, A., \& Maskell, P. (2006). Localised learning revised. Growth and Change, $37(1), 1-18$.

22. Maskell, P. (2001). Towards a knowledge-based theory of the geographical cluster. Industrial and Corporate Change, 10(4), 921-943.

23. Mayer, B. (2000). The Dynamics of Conflict Resolution: A practitioner's guide. San Fransisco: Jossey-Bass.

24. Muluk, M. R. K. 2007. Menggugat Partisipasi Publik dalam Pemerintah Daerah Sebuah Kajian Administrasi Publik dengan Pendekatan Berpikir Sistem. Malang: Banyumedia Publishing dan Lembaga Penerbitan dan Dokumentasi FIA UB.

25. Patterson, D. A. (2008). Intergovernmental Cooperation. Albany, NY: New York State Department of State Division of Local Government Services.

26. Roelandt, T. J. A., \& Pim, D. H. (1998). Cluster analysis and cluster-based policy in OECD-countries Various approaches, early results \& policy implications. Germany: The Hague/Utrecht.

27. Rosen, E. D. (1993). Improving Public Sector Productivity: Concept and Practice. London: Sage Publications.

28. Rosenbloom, D. H. (1989). Public Administration: Understanding Management, Politics, and Law in the Public Sector. New York: McGraw Hill.

29. Senge, P. M. (1990). The Fifth Discipline. New York: Double Day Currency.

30. Skartveit, H. L., Goognow, K., \& Viste, M. (2003). Visualized System Dynamics Model as Information and Planning Tools. Infoming Science. Norway: University of Bergen. 
31. Smith, B. C. (1985). Decentralization: the Territorial Dimension of the State. London: George Allen \& Unwin.

32. Steiner, M., \& Hartmann, C. (2006). Organisational learning in clusters: a case study on material and immaterial dimensions of cooperation. Regional Studies, 40(5), 493-506.

33. Strauss, A., \& Juliet, C. (1991). How to Use Qualitative Methods In Evaluation. London: Sage Publications.

34. Sukirno, S. (1976). Beberapa Aspek Dalam Persoalan Pembangunan Daerah. Jakarta: Lembaga Penerbit Fakultas Ekonomi Universitas Indonesia.

35. Sumodiningrat, G. (2001). Responsi Pemerintah Terhadap Kesenjangan Ekonomi - Studi Empiris Pada Kebijaksanaan dan Program Pembangunan Dalam Rangka Pemberdayaan Masyarakat Indonesia. Jakarta: PerPod.

36. Tambunan, T. T. H. (2001). Perekonomian Indonesia: Beberapa Masalah Penting. Jakarta: Ghalia Indonesia.

37. United Nations. 1979. Economic \& Social Commision for Asia \& The Pacific - Guidelines for Rural Center Planning. New York.

38. Webster, D., \& Larissa, M. (2000). Urban Competitiveness Assessment in Developing Country Urban Regions: The Road Forward. Washington DC: World Bank.

39. Wolfe, D. (2003). Clusters Old and New: The Transition to a Knowledge Economy in Canada's Regions. Kingston: Queen's School of Policy Studies. 